\title{
Histological and histochemical analysis of the gonadal development of males and females of Armases rubripes (Rathbun 1897) (Crustacea, Brachyura, Sesarmidae)
}

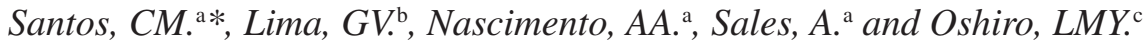 \\ ${ }^{a}$ Laboratório de Histologia e Embriologia, Instituto de Veterinária, \\ Universidade Federal Rural do Rio de Janeiro - UFRRJ, \\ Rod. BR 465, Km 07, CEP 23890-000, Seropédica, RJ, Brazil \\ 'Pós-graduação em Biologia Animal, \\ Universidade Federal Rural do Rio de Janeiro - UFRRJ, \\ Seropédica, RJ, Brazil
}

'Estação de Biologia Marinha, Universidade Federal Rural do Rio de Janeiro - UFRRJ, Rua Sereder, s/n, Itacuruçá, CEP 23880-000, Mangaratiba, RJ, Brazil

*e-mail: claricemachado@yahoo.com.br

Received August 7, 2007 - Accepted December 3, 2007 - Distributed February 28, 2009

(With 17 figures)

\begin{abstract}
The objective of this study was to provide information on the histological characteristics of the gonads of male and female Armases rubripes crabs, and to try to establish a relationship between the microscopic and macroscopic stages previously identified. Thirty-six crabs were collected by hand between February 2003 and January 2004 in banks of Spartina alterniflora on Sahy Beach in Mangaratiba, Rio de Janeiro state, Brazil. The histological analysis of the ovaries of A. rubripes demonstrated a gradual process of development of the oocytes. According to their cellular characteristics, five types of cells were distinguished: oogonia, oocyte I, oocyte II, oocyte III and oocyte IV. The ovaries showed four stages during gonadal activity: stage I (rudimentary), stage II (developing or maturing), stage III (developed or mature) and stage IV (resting). The results of the histochemical analyses showed that the ovaries vary according to the gonad development stage. The histological aspect of one section of the male gonad was always the same in all of the seminiferous tubules, where the lumen of these tubules always contained spermatozoa and/or spermatids. It was not possible to characterize the three stages of gonad development in the males. This agrees with previous reports in the literature. However, in the females there was a relationship between the gonad stages distinguished macroscopically and the results obtained through the histological and histochemical analysis, due to the presence of different cell types, as well as the lysis process and reabsorption of the oocytes in spent females.
\end{abstract}

Keywords: crab, gonadal development, histochemistry, Sesarmidae.

\section{Análise histológica e histoquímica do desenvolvimento gonadal de machos e fêmeas de Armases rubripes (Rathbun, 1897) (Crustacea, Brachyura, Sesarmidae)}

\begin{abstract}
Resumo
O objetivo deste estudo foi fornecer informações sobre as características histológicas das gônadas de machos e de fêmeas de Armases rubripes, tentando estabelecer uma relação entre os estágios microscópicos e os macroscópicos anteriormente identificados. Foram coletados manualmente 36 caranguejos, durante o período de fevereiro de 2003 a janeiro de 2004, em bancos de Spartina alterniflora na praia do Sahy Mangaratiba, Estado do Rio de Janeiro. A análise histológica dos ovários de A. rubripes demonstrou um processo gradual de desenvolvimento dos oócitos. De acordo com sua característica celular, cinco tipos de células foram distinguidos: ovogônias, oócito I, oócito II, oócito III, oócito IV. Os ovários revelaram quatro estágios de atividade gonadal: estágio I (rudimentar), estágio II (em desenvolvimento ou em maturação), estágio III (desenvolvido ou maduro), estágio IV (desovada). Os resultados das análises histoquímicas permitem afirmar que os ovários variam de acordo com o estágio de desenvolvimento gonadal. O aspecto histológico de uma sessão de gônada masculina é sempre o mesmo em todos os túbulos seminíferos, onde o lúmen deste túbulo sempre contém espermatozóides e/ou espermátides. Não foi possível a caracterização de três estágios de desenvolvimento gonadal em machos, conforme descrito previamente na literatura. Entretanto, em
\end{abstract}


fêmeas, houve uma relação entre os estágios gonadais distinguidos macroscopicamente e os resultados obtidos através da análise histológica e histoquímica, devido à presença de diferentes tipos celulares, assim como processo de lise e reabsorção dos oócitos em fêmeas desovadas.

Palavras-chave: caranguejo, desenvolvimento gonadal, histoquímica, Sesarmidae.

\section{Introduction}

Armases rubripes (Rathbun, 1897) is a small crab that is widely dispersed in varying environments. It is usually found in the tropics and subtropics of Central and South America, from Nicaragua to the River Plate (between Uruguay and Argentina) (Capítoli et al., 1977; Melo, 1996). In Brazil, it is commonly found in the South and Southeast regions, inhabiting mangrove and restinga ecosystems, as well as the axils of bromeliads and the lower portions of rivers (Fischer et al., 1997; Teixeira and Sá, 1998; Lima et al., 2006).

According to Hartnoll (1974), the consecutive changes observed during gonadal development are important, because besides enabling an estimate of physiological sexual maturity (Oshiro et al., 1999; Silva and Oshiro, 2002a, b; Cobo and Fransozo, 2003), they permit detailed visualization of the reproductive cells (Dumont and D'Incao, 2004). Furthermore, these modifications are indispensable to characterize the reproductive dynamics and to manage adaptations for the preservation and/or commercial exploitation of the populations.

The reproductive cycle of crustaceans has been widely studied, mainly of those species that have commercial value or ecological potential (Reigada and Negreiro-Franzoso, 1999; Pinheiro and Franzoso, 2002; Castiglioni and Negreiros-Fransozo, 2006). There are several studies describing the morphological aspects of the gonads, such as the morphological and histochemical aspects of the gonad of Macrobrachium rosenbergii (Moraes, 1995); the histochemical aspects of the testis and vas deferens of Goniopsis cruentata (Garcia and Silva, 2006); spermatogenesis and formation of the spermatophore in the vas deferens of Chionoecetes opilio (Sainte-Marie and Sainte-Marie, 1999); morphology and histology of the male reproductive system of the mangrove land crab Ucides cordatus (Castilho et al., 2007) and the stages of the reproductive cycle and anatomical changes occurring in the spermatic cells (Bawab and El-Sherief, 1988)

In A. rubripes, Lima and Oshiro (2006) described some aspects of the reproductive biology and characterized macroscopic aspects of the four stages of gonad development of females (immature, intermediate, developed and resting) and three stages of males (immature, intermediate and developed).

Because of the scarcity of information on the morphological aspects of crab gonads, particularly of the Sesarmidae family, the present work aims to contribute to the knowledge of the histological and histochemi- cal characteristics of the male and female gonads of A. rubripes and to establish a relationship between the microscopic and macroscopic stages previously described in the literature.

\section{Material and Methods}

Thirty-six specimens of A. rubripes were collected by hand ( 15 males, 15 females and 6 juveniles) between February 2003 and January 2004, in Spartina alterniflora banks on Sahy Beach, Mangaratiba, Rio de Janeiro State, Brazil (22 $56^{\prime} \mathrm{S}$ and $\left.44^{\circ} 01^{\prime} \mathrm{W}\right)$ (Figure 1). After capture, all of the specimens were stored in polystyrene boxes and taken to the Marine Biology Laboratory at Rio de Janeiro Federal Rural University (UFRRJ), where they were kept in aquariums under constant aeration. In the laboratory, the animals were sexed and identified according to morphotype (Lima and Oshiro, 2006). All crabs were cold-anesthetized and killed at $-20{ }^{\circ} \mathrm{C}$ during 15 minutes. The gonads were quickly dissected and fixed in Bouin's solution for eight hours. The tissues were dehydrated in increasing concentrations of ethanol, cleared in xylol and soaked in paraffin in order to make $5 \mu \mathrm{m}$ thick histological cuts with a microtome. Later, each cut was stained using hematoxylin and eosin (HE), Gomori Trichrome, periodic acid-Schiff (PAS) and Alcian blue $(\mathrm{AB}) \mathrm{pH} 2.5$, following the protocol of Junqueira and Junqueira (1983).

The gonads were analyzed through transversal and longitudinal sections. Photomicrographs were taken using an Olympus ${ }^{\circledR}$ microscope $(\mathrm{CH} 30)$ and a Nikon ${ }^{\circledR}$ digital camera (Colpix 4300).

\section{Results}

\subsection{Characterization of the female gonad}

The female reproductive system is a bilaterally symmetrical, H-shaped structure in the antero-lateral portion of the cephalothorax, composed of ovaries, which run to the posterior, joined by a transversal commissure in the antero-lateral portion of the cephalothorax, gonoducts (Figure 2a) and a specialized dilation of the gonoduct, known as the spermatheca.

The cells that constitute the ovaries are of three main types: oogonia, oocytes in different stages of development and follicle cells.

Oogonia are small, oval or rounded cells with a spherical nucleus occupying almost the entire cell, and 
the cytoplasm is intensely basophilic (Figure 3). Oocytes come from developing oogonia and are classified into four distinct cell types according to development, characterized by previtellogenesis and vitellogenesis. These four types are:

Oocytes I (oI) are characterized by having a basophilic cytoplasm and for being larger than oogonia, round and for having a spherical nucleus. These cells are varied in size and found in the proliferation zone (Figure 3).
Oocytes II (oII) are much larger than oocytes I, round or polygonal, have a strongly basophilic cytoplasm, a large, oval nucleus, and peripheral nucleoli (Figure 4).

Oocytes III (oIII) are characterized by the presence of yolk vesicles in the cytoplasm and are slightly acidophilous in routine preparations (Figures 4).

Oocytes IV (oIV) (vitellogenic) possess a varied shape (mostly polyhedral). The nucleus is difficult to visualize because the cell is filled with vacuoles and granules of yolk characterized by a strongly acidophilous mass (Figure 5).

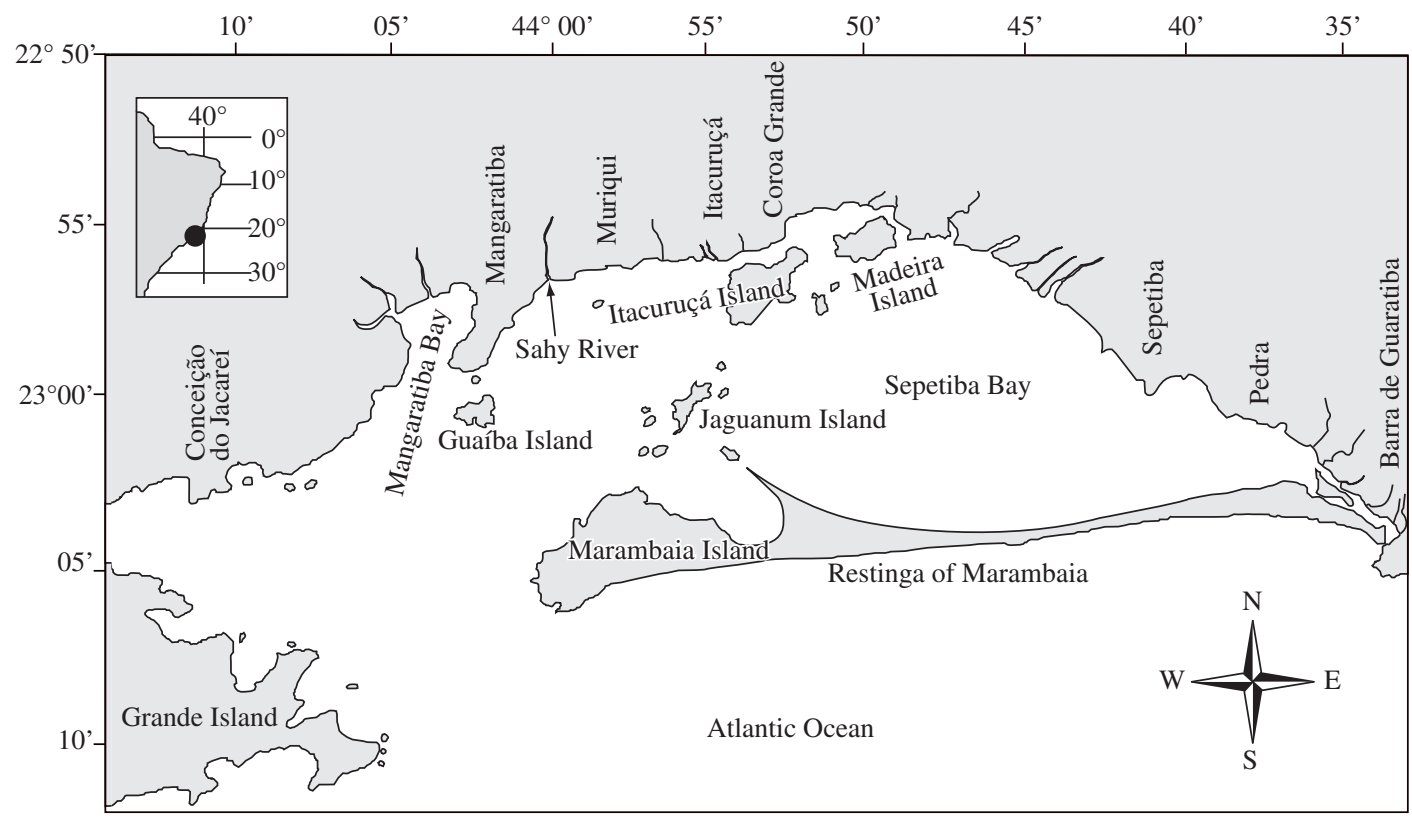

Figure 1. Map of Sepetiba Bay indicating Sahy Beach, Mangaratiba, Rio de Janeiro, Brazil.
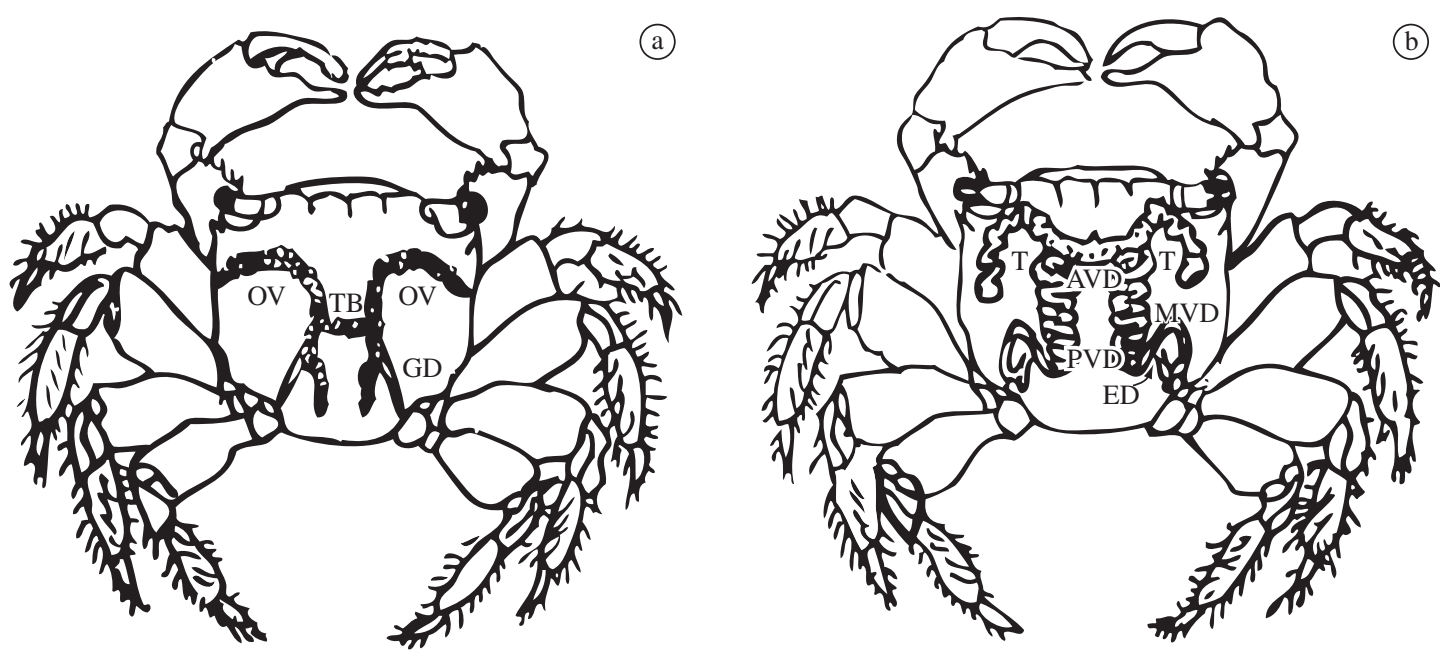

Figure 2. Diagram of the reproductive system of Armases rubripes. a) Ovaries (OV), connected by a transversal bridge (TB), gonoducts (GD); and b) Testes (T), proximal vas deferens (PVD), middle vas deferens (MVD), distal vas deferens (DVD) and ejaculatory ducts (ED). Modified by Garcia and Silva, 2006. 
The follicle cells are found around the oocytes and are responsible for supplying nutrients. They have elongated nuclei that when compressed by vitellogenic oocytes acquire a squamous aspect (Figure 6).

Microscopic analysis of the ovaries revealed four stages of gonadal activity: stage I (rudimentary), stage II (developing or maturing), stage III (developed or mature) and stage IV (resting).

\subsubsection{Stage I - Rudimentary}

There is a central proliferation zone where oogonia divide intensely, followed by oocytes that are covered by follicle cells. Oocytes I (oI) occupy a more peripheral portion of the gonad. These oocytes demonstrate a negative reaction to PAS and positive to $\mathrm{AB}$ methods.

\subsubsection{Stage II - Developing or maturing}

This stage can be subdivided into two phases. The first is previtellogenesis and the second vitellogenesis.

\subsubsection{Phase I-Previtellogenesis}

There was a central proliferation zone: oocytes I and II predominated, whose coloration was basophilic using both the HE and Gomori Trichrome methods; oocytes III (previtellogenic) appeared, which is characteristic of this phase (Figure 7).

\subsubsection{Phase II - Vitellogenesis}

The oocytes could be observed in intense vitellogenesis, with their granules very visible, and a concentration of yolk in the cytoplasm. The nucleus of these oocytes lost their rounded form, since the concentration of vitellus in the cytoplasm totally or partially covered the nucleus. In this phase, a concentration of oocytes II and III was also observed; however, the oocytes in vitellogenesis (oIV) formed the thickest zone of the parenchyma. The epithelium was reduced to one layer of flat follicle cells around oocytes III and IV. The PAS method revealed an intense coloration of oocytes IV located in the peripheral portion of the gonad, indicating the presence of neutral glycosaminoglycans in this yolk. However, the reaction was negative to PAS and positive to $\mathrm{AB}$ in the germinative zone where the oocytes in initial development were found (Figure 8).

\subsubsection{Stage III - Developed or mature}

The germinative zone appears in dispersed points of the gonad and is compressed by the mature acidophilous oocytes (Figure 9). There is no visualization of conjunctive tissue, and the ovarian capsule is very thin and breaks open easily if compressed, releasing mature oocytes. Oocytes II and III are found in small quantities,
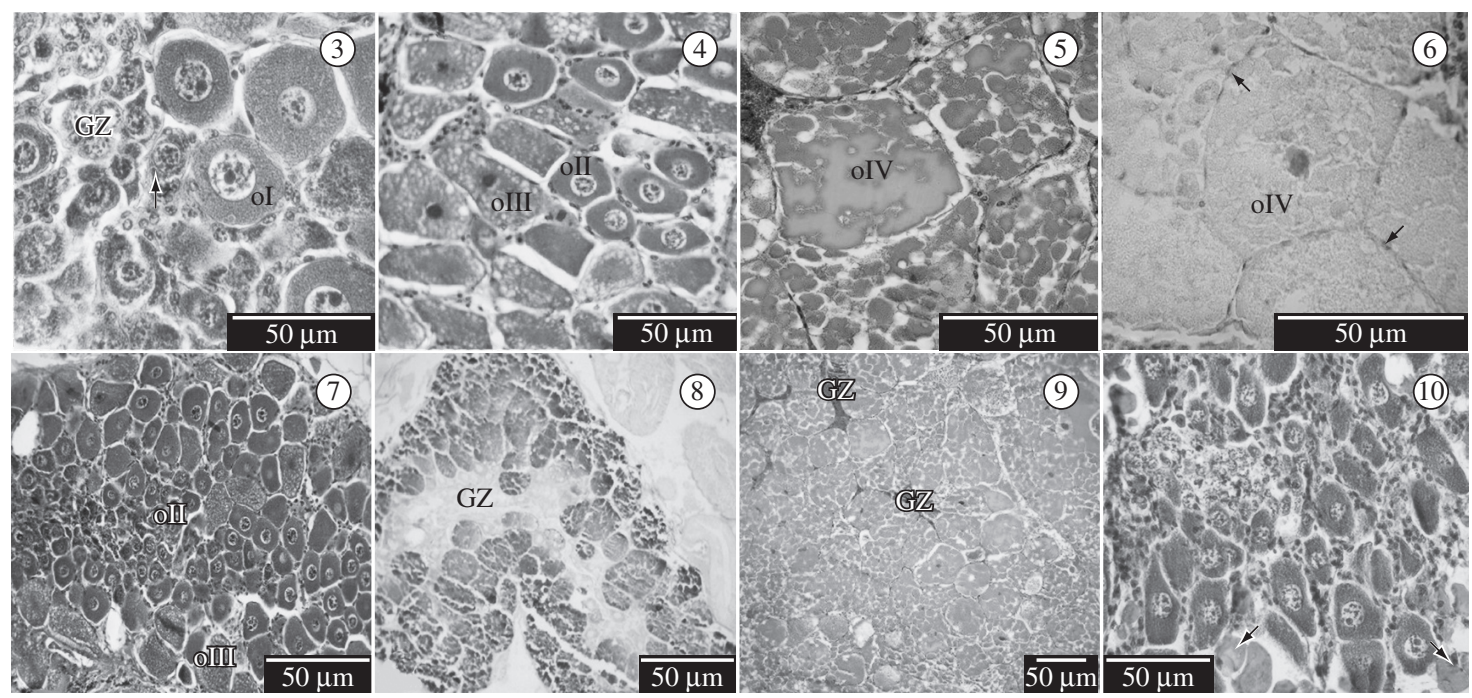

Figures 3-10. Photomicrographs of a cross section of an A. rubripes ovary. 3) Stage I of gonadal development, germinative zone (GZ), oogonia (arrow) and oocyte I. Hematoxylin and eosin. 4) Stage II - phase I of previtellogenesis, showing oocyte II and oocyte III beginning the formation of yolk with cytoplasm. Hematoxylin and eosin. 5) Oocytes IV (oIV) with polyhedral shape. The nucleus is not visualized because the cell is filled with vacuoles and granules of yolk characterized by a strongly acidophilous mass. Hematoxylin and eosin. 6) Oocyte IV in final phase of development; note the follicle cells (arrow). Alcian Blue. 7) Gonad in stage II - phase I of gonadal development, showing the predominance of oocyte II and oocytes III. Hematoxylin and eosin. 8) Gonad in stage II - phase II (vitellogenic) showing the absence of reaction to the germinative zone (GZ) and markings in the developed oocytes. PAS. 9) Gonad in the final phase of vitellogenesis, almost totally occupied by oocytes in vitellogenesis, the germinative zone (GZ) appears in dispersed points of the gonad, compressed by mature oocytes (o). Hematoxylin and eosin. 10) Gonad in stage IV of gonadal development, showing the remaining germinative zone after spawning and oocytes in the process of lysis and oocyte reabsorption (arrow). Hematoxylin and eosin. Oocyte I (oI), Oocyte II (oII), Oocyte III (oIII) and Oocyte IV (oIV). 
while oocytes IV occupy almost the entire organ. With histochemical techniques, only neutral glycosaminoglycans were evidenced in oocytes IV by the positive reaction to PAS.

\subsubsection{Stage IV-Resting}

Microscopic examination shows an ovary in the phase of total disorganization or reorganization. The remaining oocytes, in different phases of maturation, are found in the process of lysis and reabsorption (Figure 10). The oogonia and basophilic oocytes reappear, representatives of the proliferation zone formerly compressed by the mature oocytes from stage IV.

\subsection{Characterization of the male gonad}

The inner part of the male reproductive system of A. rubripes is bilaterally symmetrical, located in the antero-lateral portion of the cephalothorax and consists of testes connected by a testicular commissure (Figure 11), vas deferens and ejaculatory ducts (Figure 2b).

Each testis is formed by a whitish interwoven tubule located on the dorsal portion of the hepatopancreas, extending anterodorsally on the cephalotorax.

The testes are tubular organs, formed by lobules, where spermatogenesis takes place. They are surrounded by a simple squamous epithelium that encloses each testicular lobule (Figure 12). These lobules are formed by different germinative lineage cells, such as spermatogonia, spermatocytes, spermatids and spermatozoa.
The formation of spermatozoids starts in a peripheral region of the testicular lobule, called the germinative zone, where the spermatogonias are located, while the cells in a more advanced stage of development are found in groups called testicular cysts (Figure 13). In the germinative zone, the reaction to the histochemical tests was negative, but positive for the testicular cysts.

Microscopic analysis revealed that the spermatogonias were cube-shaped, with indistinct cytoplasm, an oval or elongated nucleus and were strongly stained by hematoxylin, giving them a strong basophilic aspect.

The spermatocytes have a relatively small, indistinct cytoplasm and a voluminous spherical or slightly elongated nucleus that is larger than that of the spermatogonias. The cytoplasm is small and acidophilous, increasing its extension according to the cell development. These cells are very frequent in the germinative epithelium and many are found in division.

On the wall of the germinative epithelium and in the lumen of the cyst, the spermatids undergo substantial morphological changes. These changes are more evident in the nucleus, which is initially spherical and then becomes elliptical in the advanced phase.

The spermatozoids are formed from the process of cell differentiation, which results in the appearance of an acrosomal vesicle in the vicinity of the nucleus. The nucleus gradually extends around the acrosomal vesicle and surrounds almost all of the vesicle area when spermiogenesis is completed. At the end of this process there

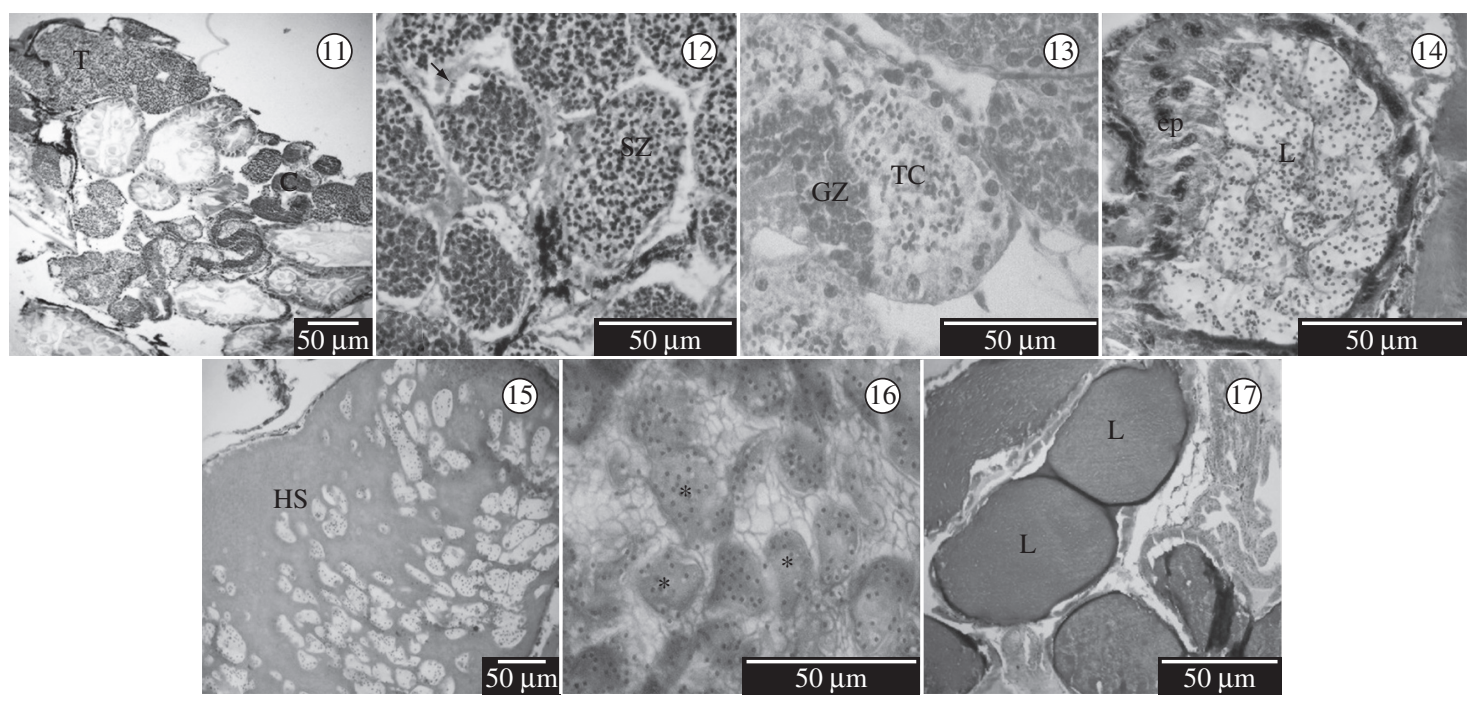

Figures 11-17. Photomicrographs of a cross section of a testis and a vas deferens of A. rubripes. 11) Testis (T) connected by a testicular commissure (C). Hematoxylin and eosin. (12) - Testicular lobule surrounded by a simple squamous epithelium (arrow) with spermatozoa (SZ) in the lumen. Hematoxylin and eosin. 13) Testes showing the germinative zone (GZ) and testicular cysts (TC). Alcian blue. 14) Proximal vas deferens is lined by a simple cylindrical epithelium (EP) with spermatozoids in the lumen (L). Hematoxylin and eosin. 15) Medial vas deferens (MVD) with a homogeneous eosiniphilic secretion in the lumen (HS). Hematoxylin and eosin. 16) MVD with numerous spermatophores immersed in a PAS-reactive substance (*). PAS. 17) Distal vas deferens with a strong positive reaction of the secretion in the lumen (L). Alcian blue. 
is a cell whose nucleus is peripheral, with the acrossome located in the central region.

The vas deferens consists of a tubule with various diameters that connects the posterior testicular region to the ejaculatory duct in the posterior part of the abdomen. It is subdivided in form and function into three different portions.

The first portion of the vas deferens, known as the proximal vas deferens (PVD), is covered by a simple cubic epithelium that becomes cylindrical in its most distal region. Mature spermatozoids, without the presence of a spermatophore, are present in the lumen of this tubule (Figure 14).

The middle vas deferens (MVD) originates in the posterior region of the pair of PVD, located in the mediodorsal region of the cephalothorax. The tube is broader and can be differentiated from the PVD by the presence of variable-sized eosiniphilic granules in the vessel lumen (Figure 15). The MVD is lined internally with a simple squamous epithelium and harbors numerous ovoid spermatophores when immersed in a PASreactive substance, indicating the presence of neutral glycosaminoglycans (Figure 16). The distal portion of the vas deferens (DVD) originates in the final portion of the MVD and is characterized by a large number of evaginations in the duct walls.

The DVD is located ventrally to the cephalothorax and is lined internally with a simple cubic epithelium. The fluid secreted by this portion was viscous and translucent and reacted strongly positive to staining with $\mathrm{AB}$, showing the presence of sulfated and carboxylated glycosaminoglycans (Figure 17). The presence of spermatophores in its lumen is infrequent in relation to MVD.

The histological aspect of one section of the gonad was always the same in all of the seminiferous tubules. The lumen of these tubules always contained spermatozoa and/or spermatids.

\section{Discussion}

Sexual maturity in brachyurans has been determined in various ways, based on analyses of morphological maturity, relative growth criteria and physiological and functional maturity (Sampedro et al., 1999; Litulo, 2005).

In this study, the histological analysis of the ovaries of $A$. rubripes demonstrated a gradual process of development of the oocytes. According to their cellular characteristics, five types of cells were distinguished: oogonia, oocyte I, oocyte II, oocyte III and oocyte IV.

In Ucides cordatus females, three stages of gonadal development were identified - developing, mature or developed, and resting (Dalabona and Silva, 2005). However, most authors divide microscopic gonadal development into five stages (immature, rudimentary, incipient maturation, mature and resting) (Vogt et al., 1989; Medina et al., 1996; Palácios et al., 1999).
The gonadal stages of the Portunus pelagicus females were classified according to the morphological characteristics of the carapace: soft-shelled females, in which two development stages were recognized (virgin and copulated females); and hard-shelled females, with six stages (copulated, ripe - late April, ovigerous - May, ripe - August, ovigerous - September, non-breeding) (Bawab and El-Sherief, 1988).

In this work it was possible to identify four histologically distinct gonadal development stages in the ovaries of A. rubripes: I (rudimentary), II (developing or maturing), III (developed or mature) and IV (resting). This classification has also been observed for Macrobrachium acanthurus (Carvalho and Pereira, 1981).

The stage I (rudimentary) ovaries of A. rubripes are characterized by the occurrence of a central proliferation zone followed by oogonia and type I oocytes toward the periphery of the gonad. This has also been observed for M. acanthurus (Carvalho and Pereira, 1981). Dumont and D'Incao (2004) observed changes in the ovaries from stage I (immature) to stage II (incipient maturation) regarding the increase in cell size and cell weight and the start of the production of yolk.

The results here indicate that stage II (developing or maturing) corresponded to the progression of gametogenesis, presenting the characteristic aspect of growth and maturation of the oocytes. In this stage, previtellogenesis and vitellogenesis are designated, under macroscopic observation, as intermediary $\mathrm{A}$ and $\mathrm{B}$, respectively by Lima et al. (2006).

In the previtellogenesis phase the basophilic cytoplasm evident in the oocytes II diminish gradually as the vitellus accumulates in the cytoplasm, becoming acidophilous in the oocytes in vitellogenesis. According to Raven (1961), this basophilic cytoplasm is especially important for the increase of the protoplasm, but not for the formation of the vitellus, justifying the change in staining affinity.

In the vitellogenic phase of $A$. rubripes, oocytes are in intense vitellogenesis and there is a large concentration of oocytes III and appearance of some oocytes IV. Carvalho and Pereira (1981) divided this vitellogenic phase according to its macroscopic characteristics into initial and advanced. The initial vitellogenic phase is characterized by turgidity, distention in the length of the ovary and beginning of the central proliferation zone with persistence of the germinative epithelium. The advanced vitellogenic phase is characterized by large ovaries, covering almost the entire stomach, with persistence of the germinative zone compressed by oocytes in vitellogenesis.

In the penaeidae Artemesia longinaris, stage II was considered incipient maturation based on statistical analysis of the diameter of the oocytes. Females in this stage were considered reproductive (Quintero and Gracia, 1998).

Stage III (developed or mature) was characterized by the ovary being almost totally occupied by oocytes in 
advanced-type IV vitellogenesis. These oocytes are large and rich in yolk. The follicle cells, evident around the oocytes in the previtellogenic stage, flatten, probably due to the tension exercised by the greatly distended oocytes over them. This has also been observed in other decapods (King, 1948; Kessel, 1968). Raven (1961) and Beams and Kessel (1963) reported that the oocytes remove the material, or part of it, from these cells to form the yolk.

Stage IV (resting) is characterized by the total post-elimination of the oocytes. In this phase, there is ovarian regeneration (with reabsorption), oocyte lysis and proliferation of the cellular elements of the connective tissue. This was also reported in Palaemon paucidens (Kamiguchi, 1971) and Artemesia longinaris (Christiansen and Scelzo, 1971). This phase may be a source of error in the macroscopic classification since it is similar to stage I, where the ovary is also difficult to visualize. Microscopic analysis, however, eliminates the possibility of error in these stages.

The results of the histological and histochemical analyses here allowed affirming that the ovaries vary according to gonadal development stage. The processes of sexual maturation, in view of the observed modifications, allowed the establishment of four development stages, thus enabling a correlation between the macroscopic characteristics observed in the previous work carried out by Lima and Oshiro (2006) and the microscopic characteristics observed in this work.

The reproductive system of $A$. rubripes males consists of paired testes, vas deferens and ejaculatory ducts and is similar to the reproductive system generally described for other brachyurans (Krol et al., 1992; Lima, 1995; Garcia and Silva, 2006; Castilho et al., 2007).

The testes are formed by seminiferous tubules and, like most Decapoda, the spermatogonia are located in the most peripheral portion of this tubule (Mota-Alves and Tomé, 1966; Nagao and Munehara, 2003).

The spermatids and the spermatozoa are difficult to distinguish. The spermatozoa do not present a spiny process, as has been reported for other brachyura (Nath, 1937; Pillai, 1960).

At the end of spermatogenesis, the sexual cells are transported to the vas deferens, where the spermatic cells are encapsulated, forming spermatophores (Hinsch and McKnight, 1988; Sainte-Marie and Sainte-Marie, 1999).

In A. rubripes, the vas deferens was divided into three distinct regions, as has been reported in other crabs (Hinsch and Walker, 1974; Johnson, 1980). However, other studies characterize two (Garcia and Silva, 2006), four (Hinsch and McKnight, 1988) and eight (ManjónCabeza and Evenness, 2000) regions. Different criteria and different microscopic and macroscopic foci may account for this diversity (Garcia and Silva, 2006).

Castilho et al., (2007) characterized the PVD by the presence of a cylindrical epithelium, spermatozoids in the lumen and absence of spermatophores, a result also observed here.
The medial portion of the vas deferens (MVD) is known for its secretory activity (Silva and Garcia, 2006). Binford (1913) and Cronin (1947) observed that a secretion of substances that allows the coiling and storage of the spermatophore occurs in the PVD.

Hinsch and McKnight (1988) also attributed the start of the formation of the spermatophore and the production of the seminal fluid to this region. Sainte-Marie and Sainte-Marie (1999) characterized two amorphous substances in C. opilio, suggesting the existence of two different types of seminal fluids. These authors also suggested that the complete development of the spermatozoon occurs only inside the spermatheca.

In A. rubripes, we observed spermatohores immersed in a secretion positive to the PAS technique, a result similar to that found in Ucides cordatus by Castilho et al., 2007. This PAS-positive secretion can induce spermiogenesis when present in large quantities (Sainte-Marie and Sainte-Marie, 1999).

The distal vas deferens is characterized by the presence of invaginations in its wall. The lumen was filled by a secretion positive to PAS and $A B$, indicating the presence of neutral and acidic glycosaminoglycans, respectively.

The results of the analysis showed that it was not possible to characterize the three gonadal development stages in males, as described by Lima and Oshiro (2006), since there is a constant process of gamete production, indicated by the presence of different spermatogenic lineage cells in the same seminiferous tubules. However, it was possible to establish a relationship between the gonad stages distinguished macroscopically by Lima and Oshiro (2006) and our histological results, due to the presence of different cell types along with the process of lysis and reabsorption of the oocytes in resting females.

\section{References}

BAWAB, FM. and EL-SHERIEF, SS., 1988. Stages of the reproductive cycle of the female crab Portunus pelagicus (L, 1758) based on the anatomical changes of the spermatheca (Decapoda Brachyura, Portunidae). Crustaceana, vol. 54, no. 2, p. $139-148$.

BEAMS, HW. and KESSEL, RG., 1963. Electron microscope studies on developing crayfish oocytes with special reference to the origin of yolk. The Journal of Cell Biology, vol. 18, p. 621-649.

BINFORD, R., 1913. The germ-cells and the process of fertilization in the crab, Menippe mercenaria. Journal of Morphology, vol. 24, no. 2, p. 147-201.

CAPÍTOLI, RR., BENVENUTI, CE. and GIANUCA, NM., 1977. Ocorrência e observações bioecológicas do caranguejo Metasesarma rubripes (Rathbun) na região estuarina da Lagoa dos Patos. Atlântica, vol. 2, no. 1, p. 50-62.

CARVALHO, HA. and PEREIRA, MCG., 1981. Descrição dos Estádios Ovariano de Macrobrachium acanthurus (Wiegmann, 1836) Crustacea, Palaemonidae) durante o ciclo reprodutivo. Ciência e Cultura, vol. 33, no. 10, p. 1353-1359. 
CASTIGLIONI, DS. and NEGREIROS-FRANSOZO, ML., 2006. Ciclo reprodutivo do caranguejo violinista Uca rapax (Smith) (Crustacea, Brachyura, Ocypodidae) habitante de um estuário degradado em Paraty, Rio de Janeiro, Brasil. Revista Brasileira de Zoologia, vol. 23, no. 2, p. 331-339.

CASTILHO, GG., OSTRENSKY, A., PIE, MR. and BOEGER, WA., 2007. Morphology and histology of the male reproductive system of the mangrove land crab Ucides cordatus (L.) (Crustacea, Brachyura, Ocypodidae). Acta Zoológica, vol. 88, no. 4 , p. 279-288.

COBO, VJ. and FRANSOZO, A., 2003. External factors determining breeding season in the red mangrove crab Goniopsis cruentata (Latreille) (Crustacea, Brachyura, Grapsidae) on the São Paulo State Northern coast, Brazil. Revista Brasileira de Zoologia, vol. 20, no. 2, p. 213-217.

CHRISTIANSEN, HE. and SCELZO, MA., 1971. Ciclo de maduración sexual y observaciones sobre la morfologia del aparato genital del camarón Artemesia longinaris Bate. Carpas, vol. 16, p. 1-22.

CRONIN, LE., 1947. Anatomy and histology of the male reproductive system of the Callinectes sapidus, Rathbun. Journal of Morphology, vol. 81, no. 2, p. 209-239.

DALABONA, G. and SILVA, JL., 2005. Período reprodutivo de Ucides cordatus (Linnaeus) (Brachyura, Ocypodidae) na Baía das Laranjeiras, sul do Brasil. Acta Biológica Paranaense, vol. 34 , no. $1,2,3,4$, p. 115-126.

DUMONT, LFC. and D'INCAO, F., 2004. Estágios de maturação gonadal das fêmeas do camarão-barba-ruça (Artemesia longinaris - Decapoda: Penaeidae). Iheringia, Série Zoologica, vol. 94, no. 4, p. 389-393.

FISCHER, EA., DUARTE, LFL. and ARAÚJO, AC., 1997. Consumption of bromeliad flowers by the crab Metasesarma rubripes in a Brazilian coastal forest. Crustaceana, vol. 70, no. 1, p. $118-120$.

GARCIA, TM. and SILVA, JRF., 2006. Testis and vas deferens morphology of the red-clawed mangrove tree crab (Goniopsis cruentata) (Latreille, 1803). Brazilian Archives of Biology and Technology, vol. 49, no. 1, p. 339-345.

HARTNOLL, RG., 1974. Variation in growth pattern between some secondary sexual charaters in crabs (Decapoda, Brachyura). Crustaceana, vol. 27, no. 2, p. 131-136.

HINSCH, GW. and WALKER, MH., 1974. The vas deferens of the spider crab, Libinia emarginata. Journal of Morphology, vol. 143 , no. 1, p. 1-19.

HINSCH, GW. and MCNIGHT, CE., 1988. The vas deferens of spanish lobster, Scyllarus chacei. Journal of Invertebrate Reproduction and Development, vol. 13, no. 33, p. 267-280.

JOHNSON, PT., 1980. Histology of the blue crab Callinectes sapidus: a model for Decapoda. New York: Praeger Publishers. $440 \mathrm{p}$.

JUNQUEIRA, LCU. and JUNQUEIRA, LMMS., 1983. Técnicas básicas de citologia e histologia. São Paulo: Santos. $123 \mathrm{p}$.

KAMIGUCHI, Y., 1971. Studies on the molting in the freshwater prawn Palaemon paucidens. I: some endogenous and exogenous factors influencing the intermolt cycle. Journal of the Faculty of Science, Hokkaido University, Series VI Zoology, vol. 18, no. 1, p. $15-23$
KING, JE., 1948. A study of the reproductive organs of the common marine shrimp, Penaeus setiferus (Linnaeus). The Biological Bulletin, vol. 94, no. 3, p. 244-262.

KESSEL, RG., 1968. Mechanisms of protein yolk synthesis and deposition in crustacean oocytes. Cell and Tissue Research, vol. 89 , no. 1, p. 17-38.

KROL, RM., HAWKINS, WE. and OVERSTREET, RM., 1992. Reproductive components. In HARRISSON, FW. and HUMES, AG. (Eds.). Microscopic anatomy of invertebrates. Decapod Crustacea: Wiley-Liss. Inc.

LIMA, AVP., 1995. Estudo do Sistema Reprodutivo de machos da lagosta verde Panulirus laevicauda (Latreille, 1817) (Decapoda: Palinuridae). Paraíba: Universidade Federal da Paraíba. 200 p. Dissertação de Mestrado.

LIMA, GV. and OSHIRO, LMY., 2006. Sexual maturity of the crab Armases rubripes (Rathbun) (Crustacea, Brachyura, Sesarmidae) in Sepetiba Bay, Rio de Janeiro, Brazil. Revista Brasileira de Zoologia, vol. 23, no. 4, p. 1078-1086.

LIMA, GV., SOARES, MRS. and OSHIRO, LMY., 2006. Reproductive biology of the sesarmid crab Armases rubripes (Decapoda, Brachyura) from an estuarine area of the Sahy River, Sepetiba Bay, Rio de Janeiro, Brazil. Iheringia, Série Zoológica, vol. 96, no. 1, p. 47-52.

LITULO, C., 2005. Population biology of the fiddler crab Uca annulipes (Brachyhura: Ocypodidae) in a tropical East African mangrove (Mozambique). Estuarine, Coastal and Shelf Science, vol. 62, p. 283-290.

MANJÓN-CABEZA, ME. and RASO, JEG., 2000. Morphological reproductive aspects of males of Diogenes pugilator (Roux, 1829) (Crustacea, Decapoda, Anomura) from southern Spain. Sarsia, vol. 85, p. 195-202.

MEDINA, A., VILA, Y., MOURENTE, G. and RODRIGUEZ, A., 1996. A comparative study of the ovarian development in wild and pond-reared shrimp, Penaeus kerathurus (Förskal, 1775). Aquaculture, vol. 148, no. 1, p. 63-75.

MELO, GAS., 1996. Manual de identificação dos Brachyura (caranguejos e siris) do litoral brasileiro. São Paulo: FAPESP. 603p. Museu de Zoologia.

MORAES, N., 1995. Morphological and histochemical aspects of the male gonad of Macrobrachium rosenbergii (Crustacea, Decapoda, Palaemonidae). Arquivos de Biologia e Tecnologia, vol. 38, p. 679-688.

MOTA-ALVES, MI. and TOME, GS., 1966. Estudo sobre as gônadas da lagosta Panulirus laevicauda (Latreille). Arquivos da Estação de Biologia Marinha da Universidade Federal do Ceará, vol. 6, no. 1, p. 1-9.

NAGAO, J. and MUNEHARA, H., 2003. Annual cycle of testicular maturation in the helmet crab Telmessus cheiragonus. Fisheries Science, vol. 69, no. 6, p. 1200-1208.

NATH, V., 1937. Spermatogenesis of the prawn, Palaemon lamarrei. Journal of Morphology, vol. 61, no. 1, p. 149-163.

OSHIRO, LMY., SILVA, R. and SILVEIRA, CM., 1999. Rendimento de carne nos caranguejos Guaiá, Menippe nodifrons Stimpson, 1859 e Guaiamum, Cardisoma guanhumi Latreille, 1825 (Crustacea, Decapoda, Brachyura) da Baía de Sepetiba/ RJ. Acta Biologica Leopoldensia, vol. 21, no. 1, p. 83-88. 
PALACIOS, E., RODRÍGUEZ-JARAMILLO, C. and RACOTA, IS., 1999. Comparison of ovary histology between different-sized wild and pond-reared shrimp Litopenaeus vannamei (=Penaeus vannamei). Invertebrate Reproduction and Development, vol. 35, no. 3, p. 251-259.

PINHEIRO, MAA., FRANSOZO, A., 2002. Reproductive dynamics of the speckled swimming crab Arenaeus cribrarius (Lamarck, 1818) (Brachyura, Portunidae), on the north coast of São Paulo State, Brazil. Journal of Crustacean Biology, vol. 22, no. 2, p. 416-428.

PILLAI, RS., 1960. Studies on the shrimp, Cardina Laevis (Heller). II. The reproductive system. Journal of the Marine Biological Association of Indian, vol. 2, no. 2, p. 226-236.

QUINTERO, MES. and GRACIA, A., 1998. Stages of gonadal development in the spotted pink shrimp Penaeus brasiliensis. Journal of Crustacean Biology, vol. 18, no. 4, p. 680-685.

RAVEN, CP., 1961. Oogenisis: the storage of developement informations. New York: Pergamon Press. 274p.

REIGADA, ALD. and NEGREIROS-FRANSOZO, ML., 1999. Maturidade sexual em Hepatus pudibundus (decapoda, Brachyura, Calappidae). Iheringia, Série Zoológica, vol. 86, p. $159-164$.

SAMPEDRO, MP., GONZÁLEZ-GUIRRIÁN, E., FREIRE, J. and MUIÑO, R., 1999. Morphometry and sexual maturity in the spider crab Maja squinado (Decapoda: Majidae) in
Galicia, Spain. Journal of Crustacea Biology, vol. 19, no. 3, p. $578-592$.

SAINTE-MARIE, G. and SAINTE-MARIE, B., 1999. Reproductive products in the adult snow crab (Chionoecetes opilio). I. Observations ons spermatogenesis and spermathophore formation in the vas deferens. Canadian Journal Zoology, vol. 77 , no. 3 , p. $440-450$.

SILVA, ZS. and OSHIRO, LMY., 2002a. Aspectos reprodutivos de Goniopsis cruentata (Latreille) (Crustacea, Brachyura, Grapsidae) na Baía de Sepetiba, Rio de Janeiro, Brasil. Revista Brasileira de Zoologia, vol. 19, no. 3, p. 907-914.

-. Crescimento em Goniopsis cruentata (Latreille, 1803) (Crustácea, Decapoda, Grapsidae) no laboratório. Revista Brasileira de Zoologia, vol. 19, no. 3, p. 915-923.

TEIXEIRA, RL. and SÁ, HS., 1998. The use of bromeliads as an alternative shelter by the grapsid crab, Metasesarma rubripes (Rathbun, 1897) of southeast Brazil. Boletim do Museu de Biologia Mello Leitão, vol. 8, p. 13-20.

VOGT, G., QUINITIO, ET. and PASCUAL, FP., 1989. Interaction of the midgut gland and the ovary in vitellogenesis and consequences for the breeding success: a comparison of unablated and ablated spawners of Penaeus monodon. In De PAUW, JN., ACKEFORS, H. and WILKINS, NE. (Ed.). Aquaculture: a biotechnology in progress. Bredene: European Aquaculture Society. p. 581-592. 